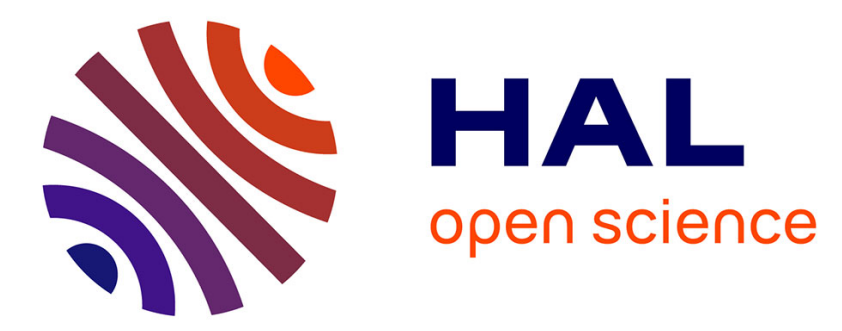

\title{
Virtual firm as a role-playing tool for biomedical education
}

\author{
O. Blagosklonov, Georges Soto-Romero, F. Guyon, N. Courjal, S. Euphrasie, \\ R. Yahiaoui, N. Butterlin
}

\section{- To cite this version:}

O. Blagosklonov, Georges Soto-Romero, F. Guyon, N. Courjal, S. Euphrasie, et al.. Virtual firm as a role-playing tool for biomedical education. 28th Annual International Conference of the IEEE Engineering in Medicine and biology society, Aug 2006, New-York, United States. pp.4204-4205, 10.1109/IEMBS.2006.259721 . hal-00194715

\section{HAL Id: hal-00194715 https://hal.science/hal-00194715}

Submitted on 14 Apr 2021

HAL is a multi-disciplinary open access archive for the deposit and dissemination of scientific research documents, whether they are published or not. The documents may come from teaching and research institutions in France or abroad, or from public or private research centers.
L'archive ouverte pluridisciplinaire HAL, est destinée au dépôt et à la diffusion de documents scientifiques de niveau recherche, publiés ou non, émanant des établissements d'enseignement et de recherche français ou étrangers, des laboratoires publics ou privés. 


\title{
Virtual Firm as a Role-Playing Tool for Biomedical Education
}

\author{
Oleg Blagosklonov, Member, IEEE, Georges Soto-Romero, Florent Guyon, Nadège Courjal, \\ Sebatien Euphrasie, Reda Yahiaoui, and Nadia Butterlin
}

\begin{abstract}
The paper describes design of a role-playing tool based on the experience of the Practice Firm which allows participants to obtain relevant and practical on-the-job experience. The students played the roles of the employees and the applicants for vacant positions at the Virtual Firm - a small business specialized in biomedical sector - founded to design the demonstration vehicle for a biomedical device. We found that this innovative concept may be used to improve the young engineers performance and to facilitate their post-graduate integration.
\end{abstract}

\section{INTRODUCTION}

$\mathrm{T}$ HE Institut Superieur d'Ingenieurs de Franche-Comté (ISIFC, or the High Institute of Engineers of FrancheComte) was created in 2001 as an internal unit of the University of Franche-Comte. Our goal is to propose a specialized training program responding to a growing demand in engineers having high level competences in scientific and clinical fields [1].

Students may enter the program with a bachelor's degree in engineering or life sciences (three-year training) or with a license degree (two-year training).

The majority of the graduates are employed by firms producing and/or commercializing medical devices and health-oriented materials and equipments such as Alcis, Arthesis, Aventis Pasteur, Biomérieux, Denstply, Imasonic, Johnson\&Johnson, Statice Santé, Sophysa, Symbios, Praxim, Protheos, Tornier, Zimmer etc.

Considering that role playing can facilitate the preparation of our students for the workplace, we have been put in a module called "Virtual Firm" in the curriculum. Role playing is indeed the best way to develop the skills of initiative, communication, problem-solving, self-awareness, and working cooperatively in teams, and these are above all will help the young engineers to understand the more subtle aspects of social relations [2].

We followed the experience of the Practice Firm concept developed in Germany during the fifties but the origin of practice firms (in the past also named "fictitious firms") can be traced back to the 17th century [3]. This model allows participants to obtain relevant and practical on-the-job experience as they work at their assigned duties and the

O. Blagosklonov, G. Soto-Romero (corresponding author), F. Guyon, adège Courjal, Sebatien Euphrasie, Reda Yahiaoui, and N. Butterlin are with the Institut Superieur d'Ingenieurs de Franche-Comté, University of Franche-Comté, 16 route de Gray, Besançon, 25030 France (phone: +33381-66-66-90; fax: +33-381-66-60-63; e-mail: gsotor@ @ 1pmo.edu). company functions in a simulated marketplace on the closed network of Practice Firms. There are over 4,000 similar firms worldwide in 40 countries consolidated in different national headquarters, themselves members of the European Practice Enterprise Network (EUROPEN), the network of networks of Practice Firms. EUROPEN's mission is to support, co-ordinate and develop services adding value to the activities carried out in its member's national networks; to promote and enhance the concept of learning in and from a simulated business environment and to expand the number of regional and national networks [3]. The students learn to work as a team and develop interpersonal skills by working with others, improving their own learning and experience and performing the various jobs within their Practice Firm. The methodology consists in:

--learning by doing,

--learning by trial and error,

--differentiated methods,

--supervising peer groups,

--departmental meetings.

\section{VIRTUAL FIRM}

Our Virtual Firm was "founded" as a biomedical SME (a small business) with the objective to design the demonstration vehicle (or its working prototype) for a high tech biomedical device including the evaluation of the technology transfer and certification aspects.

The firm has 11 positions in the departments of Human Resources, Regulatory Affairs, Sales, Marketing, Research, Quality System, and Communications (Fig. 1). Three positions (Head of Quality System, Head of Regulatory Affairs, and Process Engineer) were vacant. Interested

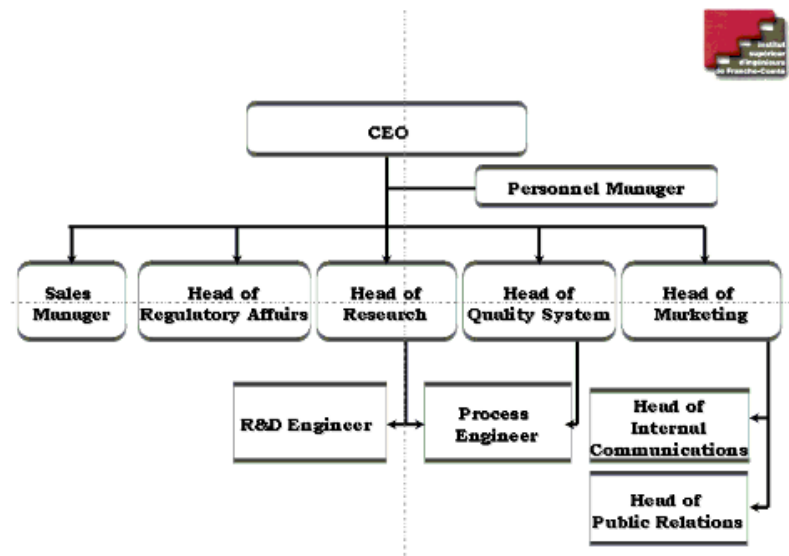

Fig. 1. Organization chart of the Virtual Firm 
individuals were interviewed for a position with and their existing skills were matched with those required for the available positions.

The randomly selected students were "hired" as the employees. The rest of the students played the roles of applicants for the vacant positions. They all contributed to the planning, organizing and monitoring of work, including preparation of minutes of meetings and press releases. Overall participation was 80 hours per student.

The project was supervised by 6 teachers specialized in the relevant fields. They evaluated the improvement of the students performance and played the roles of external auditors, consultants etc.

\section{CONCLUSION}

This first experience to integrate a business role-playing tool into biomedical education received the warmest of welcomes from the students, the teachers, and the professional advisors. All are agree that the Virtual Firm can help to better understand business goals, procedures as well as economic and legal matters. It offers an opportunity to apply theoretical knowledge in practical situations, promotes creativity and confidence.

\section{REFERENCES}

[1] O. Blagosklonov, J.C. Cardot, C. Roux, T. Ghargi, P. Picart "Institut Superieur d'Ingenieurs de Franche-Comte: Dual Skills for High Level Bio-Medical Engineers," in Proc. 27th Annu. Int. Conf. IEEE Engineering in Medicine and Biology Society, Shanghai, 2005, pp. 308-9.

[2] A. Blatner. (2002, August 2). Role playing in education. [Online]. Available: http://www.blatner.com/

[3] L. Comte. (2006, March 1). EUROPEN Bulletin. [Online]. Available: http://www.europen.info/ 